\title{
PREFERENSI SUMBER BELAJAR ONLINE MAHASISWA PENDIDIKAN EKONOMI
}

\author{
Muhammad Abdul Ghofur, Universitas Negeri Surabaya \\ muhammadghofur@unesa.ac.id \\ Wahjoedi, Universitas Negeri Malang \\ wahjoedi.fe@um.ac.id
}

\begin{abstract}
ABSTRAK
Ketersedian sumber belajar online yang semakin banyak dan beragam membuat pilihan mahasiswa semakin kaya dan pembelajaran aktif semakin menyenangkan, namun preferensi dan kemampuan mahasiswa dalam memilih sumber belajar yang tepat perlu dianalisis lebih lanjut. Penelitian ini adalah penelitian survey dengan data cross section dengan mahasiswa Program Studi Pendidikan Ekonomi Unesa sebagai subyek penelitian. Kemampuan Preferensi sumber belajar online mahasiswa Pendidikan Ekonomi Unesa didominasi oleh portal jurnal ilmiah, sosial media, laman institusi, portal berita dan blog pribadi. Sebagian besar sumber belajar ini berupa teks daripada video dengan kemudahan akses menjadi alasan utama dalam memilih sumber belajar. Informasi tentang sumber belajar ini mereka dapatkan terutama dari media sosial, saran dari teman, baru kemudian saran atau informasi dari dosen.

Kata Kunci: Preferensi, Sumber Belajar Online, Mahasiswa.
\end{abstract}

\begin{abstract}
The availability of an increasingly diverse and number of online resources makes the choice of students richer and active learning more enjoyable, but the preferences and abilities of students in choosing the right learning resources need to be further analyzed. This research is survey research with cross-section data with Unesa Economic Education Study Program students as the research subject. The ability of the online student learning resource Preference Unesa is dominated by scientific journal portals, social media, institutional pages, news portals and personal blogs. Most of these learning resources are text rather than the video with ease of access being the main reason in choosing learning resources. Information about the learning resources they get mainly from social media, advice from friends, and then advice or information from lecturers.

Keywords: Preferences, Online Learning Resources, Students.
\end{abstract}

\section{PENDAHULUAN}

Belajar akan lebih bermakna jika mahasiswa mengalami apa yang dipelajarinya, bukan mengetahuinya. Pembelajaran yang berorientasi pada penguasaan materi terbukti berhasil dalam kompetisi mengingat jangka pendek tetapi gagal dalam membekali mahasiswa bagaimana memecahkan persoalan 
dalam kehidupan nyata. Diperlukan pendekatan-pendekatan pembelajaran yang sesuai bagi mahasiswa dalam mengoptimalkan proses belajaranya, terlebih lagi pada pembelajaran ekonomi. Matakuliah ekonomi sangat erat kaitannya dengan masalah-masalah kontekstual dan selalu berkembang setiap saat. Kompleksitas ilmu ekonomi saat ini semakin meningkat, bila pembelajaran hanya mengandalkan sumber dan metode konvensional maka sudah bisa dipastikan tidak akan mampu menghasilkan lulusan yang mempunyai daya saing.

Salah satu pendekatan yang sering dipakai dalam pembelajaran di kampus adalah pendekatan pembelajaran kontekstual (Contextual Teaching and Learning /CTL). Dengan konsep itu, hasil pembelajaran diharapkan lebih bermakna bagi mahasiswa. Proses pembelajaran berlangsung alamiah dalam bentuk kegiatan mahasiswa bekerja dan mengalami, bukan mentransfer pengetahuan dari dosen ke mahasiswa. Tugas utama dosen adalah membantu dan mengarahkan mahasiswa menuju pencapaian tujuannya. Mereka lebih banyak berurusan dengan strategi daripada memberi informasi. Tugas dosen mengelola kelas dalam sebuah tim yang bekerja bersama untuk menemukan sesuatu yang baru bagi mahasiswa. Sesuatu yang baru datang dari menemukan sendiri bukan dari apa kata dosen.

Selain pendekatan kontekstual masih banyak lagi pendekatan yang bisa digunakan dalam pembelajaran di kampus. Secara garis besar peran dosen dalam pendekatan belajar berpusat pada siswa (student centered learning) tidak jauh berbeda. Dosen harus mampu menggiring siswa untuk belajar aktif dan menentukan sendiri gaya dan sumber belajar mana yang relevan dengan kebutuhannya. Dosen tidak disarankan mendominasi pembelajaran serta memonopoli sumber belajar. Hasil penelitian Ullah dkk. (2011) menunjukkan mahasiswa mempunyai preferensi yang lebih besar untuk lingkungan pendidikan yang mendukung pemahaman daripada lingkungan pendidikan yang mengandalkan transmisi informasi. Tersedianya perangkat elektronik yang canggih dan simpel membuat kebiasaan membaca mahasiswa berubah, mereka cenderung membaca lebih banyak hal dari pada membaca pada media konvensional (Wang, dkk. 2016).

Walaupun pembelajaran berpusat pada mahasiswa ini sangat baik dalam memberikan pengalaman belajar terutama pada pemahaman kontekstual dan pemecahan masalah secara riil, namun peran dosen kemudian tidak menjadi abai dalam pembelajaran. Dosen masih tetap memberikan peranan penting dalam keseluruhan proses pembelajaran. Menurut Clauss dan Geedey (2010) peran dosen masih penting dalam membantu mahasiswa mengendalikan pembelajaran mereka, memonitor pemahaman mereka, dan menilai strategi pembelajarannya.

Banyaknya sumber belajar yang bervariasi saat ini dalam satu sisi akan menguntungkan mahasiswa karena beragam pilihan yang bisa digunakan, namun di sisi lain bisa membingungkan mahasiswa dalam memilih. Kesahihan sumber belajar yang bisa dijadikan rujukan juga menjadi kendala tersendiri jika mahasiswa tidak terbiasa dalam memilah sumber belajar. Ditambah lagi maraknya informasi palsu atau tidak dapat dipercaya yang saat ini banyak bertebaran di media-media online. Walaupun pembelajaran online memberikan angin segar bagi pembelajaran di Indonesia yang pada umumnya peserta didik 
ditempatkan dan menempatkan diri pada peran pasif. Pembelajaran di kampus masih berjalan dengan dominasi dosen. Tersedianya sumber belajar elektronik ini tidak secara otomatis membuat masalah selesai. Disamping perlu ada pendekatan-pendekatan baru dalam proses belajar di kelas, perlu adanya analisis tentang perilaku penggunaan sumber-sumber belajar yang sudah banyak tersedia secara oline atau dalam jaringan (daring).

Ada beberapa kendala umum yang sering dihadapi oleh mahasiswa seperti yang disarikan dari artikel Ribble, dkk (2005) berikut: (a) mahasiswa tidak mengetahui sumber-sumber yang kredibel dan dapat dipercaya, hal ini karena keterbatasan pengetahuan dan pengalaman mahasiswa, (b) pengetahuan mahasiswa tentang situs-situs penyedia sumber informasi yang kredibel terbatas, (c) akses yang dimiliki oleh siswa terbatas karena berbayar atau tidak mengetahui situs yang dilanggan oleh kampus, (d) mahasiswa menyalin materi dari Internet untuk tugas-tugas mereka tanpa memberikan kredit kepada penulis. Masalah-masalah ini jamak terjadi dalam dunia pendidikan tinggi di Indonesia.

Peran dosen sangat penting dalam hal ini, terutama untuk memberikan informasi awal tentang etika akademis serta mengontrol perilaku belajar mahasiswanya. Standar peran dosen atau pendidik menurut International Society for Technology in Education (ISTE) 2017 diantaranya adalah : (a) Pendidik terus meningkatkan kemampuan mereka dengan belajar dari dan dengan orang lain serta menjelajahi praktik-praktik yang terbukti dan menjanjikan dengan memanfaatkan teknologi untuk meningkatkan pembelajaran siswa, (b) Pendidik mencari peluang untuk mendukung pemberdayaan dan keberhasilan siswa dan untuk meningkatkan pengajaran dan pembelajaran, (c) Pendidik mengilhami siswa untuk berkontribusi secara positif dan bertanggung jawab dalam berpartisipasi di dunia digital, (d) Pendidik mendedikasikan waktu untuk berkolaborasi dengan rekan kerja dan siswa untuk meningkatkan penerapan, menemukan dan berbagi sumber daya dan ide, serta memecahkan masalah, (e) Pendidik mendesain kegiatan autentik yang berorientasi pada peserta didik dan lingkungan dengan mengenali dan mengakomodasi variabilitas pembelajar, (f) Pendidik memfasilitasi pembelajaran dengan teknologi untuk mendukung pencapaian standar siswa, dan (g) Pendidik memahami dan menggunakan data untuk mendorong instruksi mereka serta mendukung siswa dalam mencapai tujuan pembelajaran mereka.

Standar untuk mahasiswa atau peserta didik dalam beraktifitas di dunia digital juga sudah dirumuskan dalam ISTE. Standar ISTE untuk peserta didik tahun 2016 diantaranya adalah: (a) mahasiswa memanfaatkan teknologi untuk mengambil peran aktif dalam memilih, mencapai dan menunjukkan kompetensi dalam tujuan pembelajaran mereka, (b) mahasiswa mengakui hak, tanggung jawab, dan peluang untuk hidup, belajar, dan bekerja di dunia digital yang saling terhubung, dan mereka bertindak dan membuat model dengan cara yang aman, legal dan etis, (c) mahasiswa secara kritis mengumpulkan berbagai sumber daya menggunakan alat digital untuk membangun pengetahuan, menghasilkan artefak kreatif dan membuat pengalaman belajar yang berarti bagi diri mereka sendiri dan orang lain, (d) mahasiswa menggunakan berbagai teknologi dalam proses desain untuk mengidentifikasi dan memecahkan masalah dengan menciptakan solusi baru, berguna atau imajinatif, (e) 
mahasiswa mengembangkan dan menggunakan strategi untuk memahami dan memecahkan masalah dengan cara memanfaatkan kekuatan teknologi untuk mengembangkan dan menguji solusi, (f) mahasiswa berkomunikasi dengan jelas dan mengekspresikan diri secara kreatif untuk berbagai tujuan menggunakan platform, alat, gaya, format dan media digital yang sesuai dengan tujuan mereka, (g) mahasiswa menggunakan alat digital untuk memperluas perspektif mereka dan memperkaya pembelajaran mereka dengan berkolaborasi dengan orang lain dan bekerja secara efektif dalam tim lokal dan global.

Sumber daya pembelajaran yang begitu melimpah di dunia internet, membuka peluang bagi siapapun untuk memanfaatkannya, tinggal bagaimana mahasiswa mampu memilih dan menggunakannya sesuai dengan kebutuhan pembelajaran mereka. Perilaku mahasiswa dalam penggunaan sumber belajar ini perlu deksplorasi dan dianalisis oleh dosen sebagai dasar perancangan sampai evaluasi pembelajaran yang dilakukan. Dalam hal ini dosen perlu membagi informasi tentang sumber-sumber belajar yang kredibel dan mutakhir bagi para mahasiswanya. Walaupun ada sedikit perbedaan preferensi pembelajaran daring antara mahasiswa dan dosen, dimana mahasiswa lebih memperhatikan kekayaan dan kegunaan suatu konten, namun pada dasarnya mereka sama-sama menganggap dukungan "kapan saja" dan "dimana saja" merupakan hal yang penting (Lai, dkk. 2016).

Melihat pentingnya mengidentifikasi preferensi mahasiswa terhadap sumber belajar online untuk mendukung pembelajaran mata kuliah ekonominya maka penelitian ini menarik untuk dilakukan, Karena pada kenyataannya mahasiswa seringkali tidak mampu memilih secara tepat sumber belajar yang bermanfaat bagi pembelajarannya (Clarebout dan Elen, 2008). Dalam penelitian ini akan dianalisis sumber belajar online apa saja yang sering digunakan oleh mahasiswa, darimana mereka mendapatkan informasi tentang sumber belajar tersebut, serta bagaimana perilaku mahasiswa dalam menggunkannya. Diharapkan hasil penelitian ini mampu memberi sumbangan dan masukan berarti bagi dosen maupun mahasiswa dalam upaya peningkatan kualitas pembelajaran ekonomi yang dilakukan.

\section{METODE PENELITIAN}

Metode penelitian yang digunakan dalam penelitian ini adalah metode penelitian survei cross- sectional. Pengumpulan data pada penelitian survei bisa digunakan untuk menguji hipotesis atau menjawab pertanyaan tentang pendapat orang tentang topik atau masalah. Survei adalah instrumen untuk mengumpulkan data yang menggambarkan satu atau lebih karakteristik dari populasi tertentu. Penelitian survei dapat digunakan untuk mengumpulkan informasi tentang keyakinan, sikap, perilaku, dan komposisi demografi kelompok. Data survei dikumpulkan dengan meminta mahasiswa Program Studi Pendidikan Ekonomi Universitas Negeri Surabaya (Unesa) menjawab serangkaian pertanyaan dalam kuesioner yang diberikan. Survei cross-sectional adalah survei di mana data dikumpulkan dari individu-individu terpilih pada satu titik waktu. Desain cross-sectional efektif untuk memberikan gambaran 
tentang perilaku, sikap, dan keyakinan saat ini dalam suatu populasi (Gay, 2012).

Penelitian ini berusaha memotret preferensi sumber belajar online yang digunakan oleh mahasiswa pendidikan ekonomi. Yang dimaksud sumber belajar online di sini adalah sumber belajar yang tersedia secara online dan dapat diakses oleh setiap mahasiswa setiap saat. Sumber belajar online ini bisa berupa teks, audio, video maupun media interaktif. Subyek penelitian ini adalah para mahasiswa aktif Program Studi Pendidikan Ekonomi angkatan tahun 2014 sampai 2017 yang telah mengikuti pembelajaran matakuliah pengantar ekonomi makro dan pengantar ekonomi mikro yang berjumlah kurang lebih 320 mahasiswa. Penentuan jumlah sampel minimal menggunakan rumus sebagai berikut (Suliyanto, 2006):

$$
n=\frac{N}{1+N e^{2}}
$$

$e$ adalah bound of error yang dikehendaki yaitu 5\%, $N$ jumlah mahasiswa sebagai populasi yaitu 320 mahasiswa, dan $n$ adalah ukuran sampel minimal yang diperlukan. Maka sampel minimal dengan bound of error 5\% dapat dihitung sebagai berikut:

$$
\begin{aligned}
& n=\frac{320}{1+320(0,05)^{2}} \\
& n=177,78
\end{aligned}
$$

dari hasil perhitungan menggunakan rumus tersebut diperoleh kebutuhan sampel minimal adalah 178 mahasiswa sebagai responden.

Sampel diambil dengan menggunakan teknik snowball sampling. Snowball sampling adalah proses pemilihan sampel menggunakan jaringan. Beberapa mahasiswa dipilih dan kemudian diminta untuk mengidentifikasi mahasiswa lain untuk dijadikan bagian dari sampel. Informasi dikumpulkan dari mahasiswa-mahasiswa tersebut dilanjutkan sampai jumlah yang diperlukan tercapai yaitu 178 mahasiswa. Waktu pengumpulan data dilaksanakan selama 30 hari pada bulan Februari sampai dengan Maret 2018.

\section{HASIL PENELITIAN DAN PEMBAHASAN}

Sejumlah informasi utama yang dikumpulkan dari penelitian ini diantaranya adalah laman sumber belajar yang diakses, media yang dipilih, serta dari mana mahasiswa mendapat informasi tentang sumber belajar. Responden memberikan tanggapan secara tertutup dan terbuka. Pada tanggapan tertutup responden diberi pilihan jawaban yang sudah disediakan, sedangkan tanggapan terbuka responden disodori pertanyaan yang dapat dijawab dengan jawaban bebas namun singkat.

Laman atau situs sumber belajar yang diakses adalah laman yang menyediakan sumber belajar bagi para mahasiswa. Laman ini bisa berupa blog, laman institusi, portal artikel ilmiah, portal berita, pasar aplikasi, sosial media dan sejenisnya. Hasil yang didapat dari survei menunjukkan tanggapan yang cukup beragam dari mahasiswa. Namun, secara umum yang paling populer adalah laman portal jurnal ilmiah dan sosial media. Secara berurutan sumber 
online favorit bagi merekan adalah: 1) portal jurnal ilmiah, 2) sosial media, 3) laman institusi, 4) portal berita, dan 5) blog pribadi.

Alasan utama yang dikemukakan oleh mahasiswa ketika memilih sumber belajar tersebut adalah kemudahan akses, sedangkan alasan kredibilitas hanya menempati urutan ke empat. Secara umum alasan mahasiswa ini disajikan pada tabel 1.

Tabel 1. Alasan Memilih Sumber Belajar Online

\begin{tabular}{clr}
\hline No & Alasan & Persentase \\
\hline 1 & Mudah diakses & 47,69 \\
2 & Gratis & 20,38 \\
3 & Mutakhir & 16,54 \\
4 & Dapat dipercaya & 10,77 \\
5 & Alasan lain & 4,62 \\
\hline
\end{tabular}

Mahasiswa pada umumnya mendapat informasi awal tentang sumbersumber belajar online dari media sosial dan informasi dari teman, sedangkan pada urutan selanjutnya adalah berdasarkan saran dari dosen. Untuk mengakses sumber belajar tersebut mahasiswa masih mengandalkan mesin pencari dari pada langsung menuju laman penyedia sumber belajar. Cara ini sangat dominan dan cenderung menjadi pola utama mereka. Ketika mencari sumber belajar untuk keperluan pembelajarannya, mahasiswa cenderung memanfaatkan informasi awal yang diperoleh dari media sosial atau menanyakan informasi terkait dengan sumber belajar tersebut kepada temannya kemudian mencarinya melalui mesin pencari.

Pemanfaatan media sosial dan daring sangat dominan bagi mahasiswa. Bagi mereka keberadaannya sangat membantu dalam pelaksanaan penelitian ilmiah dan selalu menjadi acuan utama untuk mencapai target akademisnya. Seringkali materi pembelajaran dari dosen maupun materi yang mereka dapatkan dari sumber secara kolaboratif dibagikan oleh para mahasiswa dan sering digunakan untuk rujukan bersama dalam pembelajarannya. Kontenkonten ini sering dibagikan melalui grup-grup media sosial seperti Whatsapp atau Facebook. Hasil penelitian ini tidak jauh berbeda dengan hasil penelitian Ajegbomogun dan Oduwole (2017) pada mahasiswa pascasarjana di Afrika. Simpulan penelitian mereka mengungkapkan bahwa media sosial telah membuat pengaruh signifikan pada hasil pembelajaran responden. Penelitian Howard (2018) juga menunjukkan bahwa mahasiswa menginginkan adanya konten-konten pembelajaran pada media sosial mereka terutama Facebook, Instagram dan Twitter.

Merujuk pada hasil penelitian Clarebout dan Elen (2008) pembelajaran aktif atau terbuka pada umumnya mengasumsikan bahwa peserta didik dapat pengatur dirinya dengan baik. Dengan kata lain mahasiswa diasumsikan mempunyai self regulated learning yang baik. Dalam lingkungan seperti itu, peserta didik memiliki kebebasan, kontrol dan keputusan penggunaan berbagai sumber belajar. Namun, pada kenyataannya mahasiswa sering tidak memiliki asumsi tersebut, mereka tidak dapat memutuskan sumber belajar apa yang mungkin bermanfaat untuk pembelajarannya. Hasil penelitian tersebut juga 
mengungkapkan bahwa karakteristik penggunaan sumber dan media belajar dimoderasi oleh faktor lingkungan, terutama saran.

Peran dosen dalam memberi saran atau sebagai role model dalam mengakses sumber belajar yang bermanfaat bagi pembelajaran nampak masih kurang menurut mahasiswa. Saran dosen ini cukup penting bagi mahasiswa bila melihat alasan mahasiswa dalam mengakses sumber online ini. Seperti yang telah disajikan pada tabel di atas bahwa pertimbangan utama mahasiswa adalah kemudahan akses dibanding alasan lain. Pilihan sumber belajar yang mempunyai kebermanfaatan tinggi menjadi tidak efisien. Padahal di satu sisi kampus sudah melanggan portal-portal jurnal ilmiah internasional yang kredibel seperti Ebscohost, Gale Group, dan Springer. Selain itu masih banyak lagi portal jurnal ilmiah yang menyediakan akses penuh pada penggunanya pada setiap artikelnya secara gratis (open access).

Bila mahasiswa mampu memaksimalkan portal-portal database jurnal ilmiah ini maka sumber belajar yang diakses tidak hanya lebih kredibel, tetapi sebenarnya lebih mudah diakses karena sebagaian besar penyedia jasa ini sudah mendesain sedemikian rupa tampilan dan navigasi lamannya sesuai dengan kebutuhan penggunanya yaitu para akademisi. Sosialisasi dan pengkondisian penggunaan fasilitas ini perlu ditingkatkan di kalangan mahasiswa. Terlebih hasil penelitian Ricoy dan Pino (2007) yang menyatakan mahasiswa pendidikan sosial bukan pengguna yang paling sering menggunakan teknologi baru, dan bahwa mereka biasanya meniru perilaku dosen mereka dalam aplikasi teknologi pendidikan mereka.

Bila melihat pilihan mahasiswa pada bentuk atau media sumber belajar yang diakses dimana sebagian besar berupa teks. Pada gambar 1. disajikan preferensi media belajar yang disukai oleh mahasiswa dimana 56\% berupa teks, $35 \%$ adalah media video, $7 \%$ aplikasi interaktif, dan hanya $2 \%$ berupa media audio. Bila melihat data ini seharusnya portal-portal jurnal ilmiah yang dilanggan kampus menjadi andalan mahasiswa dalam mencari sumber belajarnya.

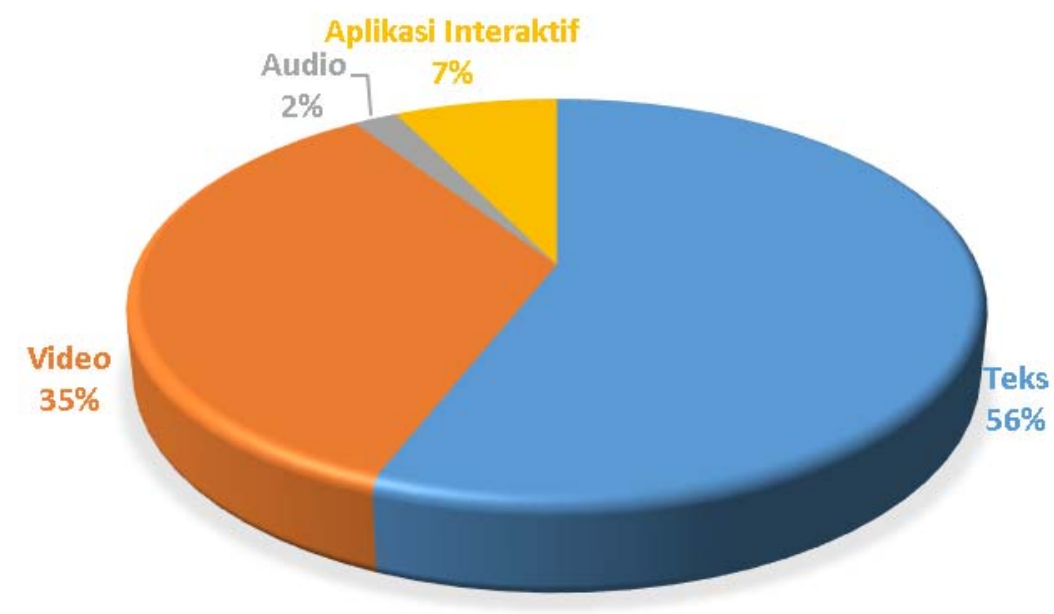

Gambar 1. Media belajar yang sering diakses oleh mahasiswa Pendidikan Ekonomi Unesa 
Hasil penelitian Pechenkina dan Aeschliman (2017) juga mengkonfirmasikan bahwa mahasiswa umumnya menggunakan teknologi pendidikan dengan cara yang sempit, jarang terlibat dengan alat teknologi, kecuali jika disajikan kepada mereka sebagai bagian integral dari pembelajaran mereka atau jika mereka sudah akrab dengan alat tertentu dan atau memandangnya sebagai sesuatu berguna bagi mereka. Peran dosen dalam pembelajaran aktif oleh mahasiswa dalam hal ini masih menjadi komponen yang penting seperti yang diungkapkan oleh Clauss dan Geedey (2010).

\section{SIMPULAN}

Preferensi sumber belajar online mahasiswa Pendidikan Ekonomi Unesa didominasi oleh portal jurnal ilmiah, sosial media, laman institusi, portal berita dan blog pribadi. Sebagian besar sumber belajar ini berupa teks daripada video atau aplikasi interaktif. Kemudahan akses menjadi alasan utama dalam memilih sumber belajar dibanding alasan-alasan lain seperti kemutakhiran dan krediilitas. Informasi tentang sumber belajar ini mereka dapatkan terutama dari media sosial, saran dari teman sedangkan saran atau informasi dari dosen masih belum optimal menentukan preferensi sumber belajar online mereka. Asumsi bahwa mahasiswa mampu menentukan sumber belajarnya secara mandiri perlu dikaji lebih jauh. Peran dosen dalam memprosikan perilaku penggunaan sumber belajar yang kredibel sekaligus mudah perlu ditingkatkan.

\section{DAFTAR RUJUKAN}

Ajegbomogun F.O., and Oduwole O.K. 2017. "Social media trends and collaborative learning for scholarly research among postgraduate students". Proceedings of the European Conference on E-Learning, ECEL. 2010-October: 9-17.

Clarebout, Geraldine, and Jan Elen. 2008. "Tool use in open learning environments: In search of learner-related determinants". Learning Environments Research. 11 (2): 163-178. DOI:10.1007/s10984-0089039-2

Clauss, Jon, and Kevin Geedey. 2010. "Knowledge Surveys: Students Ability to Self-Assess". Journal of the Scholarship of Teaching and Learning. 10 (2): $14-24$.

Gay, Lorrie R., Mills, Geoff, and Airasian, Peter W.. 2012. Educational Research: competencies for analysis and applications. [S.1.]: Pearson.

Howard, Heather A. 2018. "Academic Libraries on Social Media: Finding the Students and the Information They Want". Information Technology and Libraries. 37 (1): 8. DOI:10.6017/ital.v37i1.10160 
International Society for Technology in Education, Standards for Educators. 2017. Diakses tanggal $20 \quad$ maret 2018. https://www.iste.org/trackedlink?link=4067.

International Society for Technology in Education, Standards for Students. 2016. Diakses tanggal $20 \quad$ maret 2018. https://www.iste.org/trackedlink?link=3908.

Lai, Chiu-Lin, Gwo-Jen Hwang, Jyh-Chong Liang, and Chin-Chung Tsai. 2016. Differences between mobile learning environmental preferences of high school teachers and students in Taiwan: a structural equation model analysis. Educational Technology Research and Development. 64 (3): 533-554. DOI: 10.1007/s11423-016-9432-y

Pechenkina, Ekaterina, and Carol Aeschliman. 2017. What Do Students Want? Making Sense of Student Preferences in Technology-Enhanced Learning. Contemporary Educational Technology. 8 (1): 26-39.

Ribble, M. S., Bailey, G. D., \& Ross, T. W. (2005). Digital citizenship: Addressing appropriate technology behavior. Learning \& Leading with Technology, 32(1), 7-11.

Ricoy, Carmen, and Margarita Pino. 2007. Use of Technological Resources by Social Education Students in Spain. Higher Education in Europe. 32 (23): 241-248. DOI: 10.1080/03797720701840831

Suliyanto. 2006. Metode Riset Bisnis. Yogyakarta : Andi Offset.

Ullah, Raza, John T.E. Richardson, and Muhammad Hafeez. 2011. Approaches to studying and perceptions of the academic environment among university students in Pakistan. Compare: A Journal of Comparative and International Education. 41 (1): 113-127. DOI: $10.1080 / 03057921003647065$

Wang, Peng, Dickson K.W. Chiu, Kevin K.W. Ho, and Patrick Lo. 2016. Why read it on your mobile device? Change in reading habit of electronic magazines for university students. The Journal of Academic Librarianship. 42 (6): 664-669. DOI: 10.1016/j.acalib.2016.08.007 
